\title{
Manajemen Team Teaching di Madrasah Ibtidaiyah
}

\author{
1Ferina Widyawati, ${ }^{2 *}$ Saiful Anwar, ${ }^{3}$ Happy Susanto, ${ }^{4}$ Rohmadi \\ 1,2,3,4Universitas Muhammadiyah Ponorogo \\ *saipulanwar090@gmail.com
}

\begin{abstract}
Abstrak
MI Muhammadiyah 6 Nglegok Jenangan Ponorogo merupkan sebuh lembaga pendidikan dibawah naungan organisasi besar dunia yaitu Muhammadiyah. MI Muhammadiyah 6 Nglegok Jenangan Ponorogo dalam pembelajarannya menggunakan metode Team Teaching agar proses belajar mengajar bisa berjalan dengan baik dan sesuai dengan target yang telah ditentukan madrasah. Penelitian ini bertujuan untuk mendeskripsikan mengenai manajemen Team Teaching, faktor pendukung dan faktor penghambat manajemen Team Teaching yang ada di MI Muhammamdiyah 6 Nglegok Jenangan Ponorogo. Penelitian ini merupakan penelitian kualitatif pendekatan deskriptif yang diarahkan kepada lapangan dan menggunakan pendekatan khusus ke umum yang tidak memutuhkan kajian teori. Penelitian ini dalam pengumpulan datanya menggunakan metode wawancara, obeservasi dan dokumentasi, yang dimana hal itu dapat menjawab tentang manajemen Team Teaching di MI Muhammadiyah 6 Nglegok Jenangan Ponorogo. Hasil dari penelitian ini disimpulkan sebagai berikut : (1) Manajemen Team Teaching yang ada di MI Muhammadiyah 6 Nglegok Jenangan Ponorogo dalam satu kelas diampu oleh dua orang guru, dimana guru yang satu fokus kepada adab dan mata pelajaran umum, sedangkan guru yang satu fokus kepada al qur'an atau tahfidz dan pelajaran agama; (2) Faktor Pendukung dalam pelaksanaan metode Team Teaching di madrasah yaitu adanya tim pengembang, Kepala Madrasah,Guru, Siswa dan juga sarana Prasarana yang memadai,sedangkan yang menjadi faktor penghambat yaitu kurangnya komunikasi dengan walimurid sehingga masih banyak walimurid yang belum paham akan program yang ada di Madrasah.
\end{abstract}

Kata kunci: Manajemen, Team Teaching, Madrasah Ibtidaiyah.

\begin{abstract}
MI Muhammadiyah 6 Nglegok Jenangan Ponorogo is an educational institution under the auspices of the world's largest organization, Muhammadiyah. In their learning, MI Muhammadiyah 6 Nglegok Jenangan Ponorogo uses the Team Teaching method so that the teaching and learning process can run well and by the targets set by the madrasa. This study aims to describe the management of Team Teaching, the supporting and inhibiting factors of Team Teaching management at MI Muhammamdiyah 6 Nglegok Jenangan Ponorogo. This research is qualitative research with a descriptive approach directed to the field and uses a general system that does not require a theoretical study. In this research, the data collection uses interview, observation, and documentation methods to answer the management of Team Teaching at MI Muhammadiyah 6 Nglegok Jenangan Ponorogo. The results of this study were concluded as follows: (1) Management of the Teaching Team at MI Muhammadiyah 6 Nglegok Jenangan Ponorogo in one class led by two teachers, where one teacher focused on etiquette and general subjects, while the other teacher focused on al Qur'an or tahfidz and spiritual lessons; (2) Supporting factors in implementing the Team Teaching method in madrasas are the existence of a development team, Madrasa Heads, Teachers, Students and also adequate infrastructure, while the inhibiting factor is the lack of communication with parents so that there are still many parents who do not understand the program. Is in the Madrasa.
\end{abstract}

Keywords: Management, Team Teaching, Madrasah Ibtidaiyah. 


\section{PENDAHULUAN}

Pendidikan merupakan sebuah usaha sadar dan juga terencana untuk mewujudkan kegiatan belajar dan belajar agar siswa dapat mengembangkan potensi diri yang dimiliki seperti kekuatan spiritual keagamaan, pengendalian diri, kepribadian, kecerdasan, akhlak mulia, serta keterampilan yang diperlukan dirinya, masyarakat, bangsa dan negara (Peraturan Pemerintah RI, 2003). Pendidikan sebagai ujung tombak dari kemajuan bangsa negera ini, dimana bangsa yang maju merupakan bangsa yang pendidikannya kualitasnya terjamin, karena generasi penerus harus berpendidikan dan akan berperan penting dalam proses persiapan generasi emas Indonesia tahun 2045 yang akan datang (Arief, 2002). Pendidikan terutama di Indonesia sangatlah penting bagi setiap orang karena dengan pendiidkanlah mereka akan meneruskan keberlangsungan hidupnya dan untuk tetap melakukann aktivitas sosial dengan orang lain dan lingkungan masyarakat (Anwar, 2021).

Pendidikan merupakan salah satu peran yang sangat penting untuk meningatkan sumnber daya manusia yang berkualitas dan berpengetahuan tinggi (Muhaimin, 2004). Revolusi industri 4.0 merupakan salah satu tantangan perkembangan zaman di Indonesia, karena zaman ini merupakan zaman yang serba teknologi (Mubarak, 2018). Jika kebanyakan orang tidak menempuh pendidikan maka bisa jadi mereka akan gagap akan teknologi yang semakin hari semakin canggih.

Penjelasan diatas terkait dengan pentingnya sebuah pendidikan bagi setiap orang, karena memang dengan pendidikanlah hidup kita akan terjamin. Tidak bisa dipungkiri bahwa sekarang ini merupakan zaman yang serba teknologi, jika masih ada orang yang tidak bisa mengoperasikan handphone contohnya, mereka akan ketinggalan zaman.

Pengoptimalan sebuah pendidikan tentunya tidaklah lepas dari sistem ataupun kompetensi pengajar dan pembelajaran yang ada dalam suatu lembaga atau sekolah (Gazali, 2013). Pembelajaran merupakan suatu proses yang dilakukan oleh individu atau kelompok secara sadar untuk mengubah sikap dari tidak tahu menjadi tahu semasa hidupnya (Yani, Setyowat, Islamiyah, \& Pranggono, 2014). Sedangkan proses belajar mengajar adalah suatu kegiatan yang didalamnya terjadi proses belajar siswa dan guru dan terjadi interaksi diantaranya, yaitu antara guru dan siswa, sehingga terdapat perubahan pada siswa mulai dari perubahan sikap atau perilaku, dalam hal pengetahuan dan juga keterampilan (Hamalik, 2001).

Sebuah lembaga pendidikan dalam proses pembelajaran tentunya seorang pendidik atau guru mengacu pada kurikulum yang ada pada masing - masing sekolah (Siregar, Zahra, \& Bujuri, 2020). Sudah menjadi hal paten bahwa kurikulum sekolah juga mengaharuskan seorang guru untuk tidak hanya memiliki kemampuan di bidang pengetahuan tetapi juga harus mampu untuk merancang sebuah metode pembelajaran dan melaksanakan proses pembelajaran yang aktif, kreatif dan inovatif (Ridwan \& Ikhwan, 2021).

Guru menjadi sumber utama dalam proses pembelajaran hal tersebut juga harus didukung oleh sarana prasarana yang dimiliki oleh lembaga sekolah (Darmadi, 2015). Jika hal tersebut tidak terpenuhi maka proses pembelajaran yang dilaksanakan akan terkendala dan kurang maksimal. Oleh karena itu, pihak sekolah harus memberikan pelayanan yang layak kepada guru maupun siswa siswi nya. Selanjutnya guru juga terkendala dalam hal pengelolaan kelas dan juga pengkondisian siswa, tidak bisa dipungkiri bahwa kemampuan setiap anak atau peserta didik itu sangatlah varian (Anwar, 2022). Hal ini menjadi perhatian khusus bagi seorang guru untuk tetap mengawasi peserta didik yang pengetahuannya kurang dibandingkan dengan peserta didik yang lain.

Berkaitan dengan hal tersebut maka pendidik harus mampu untuk menyajikan dan merancang beberapa metode pembelajaran yang paling efisien dan berkualitas 
tentunya dalam sebuah pembelajaran di kelas, hal ini agar peserta didik mampu memahami materi yang disampaikan oleh guru dengan baik, hak siswa dapat terpenuhi dan juga mampu untuk mewujudkan visi,misi dan tujuan sekolah (Afandi, 2013). Perlu diketahui oleh semua pendidik atau guru bahwa, peserta didik yang ada dikelas bisa menerima materi dengan baik karena faktor metode yang digunakan oleh guru dalam penyampaian materi di kelas (Ramadhani et al., 2020).

Jika dilihat, kegiatan belajar mengajar yang dilaksanakan oleh guru pada saat ini masih sangat stagnan dan biasa saja dan masih banyak kegiatan yang cenderung dilakakukan secara individu dalam melakukan pengelolaan pembelajaran seperti merencanakan, melaksanakan maupun menilai pembelajaran siswa (Usman \& Setiawati, 1993). Seiring dengan perkembangan zaman, kini dibutuhkan seorang pendidik yang mampu memilih, merancang dan menerapkan metode pembelajaan yang tepat guna untuk peningkatan kualitas pendidikan. Salah satu metode yang saat ini menjadi topik hangat dikalangan pendidikan yaitu mengenai metode Team Teaching sebagai alternatif mengatasi kurang efektifnya pembelajaran selama kegiatan belajar mengajar di kelas (Maryamah, 2016). Team Teaching merupakan salah satu cara pembelajaran yang melibatkan dua orang guru atau lebih dalam proses pembelajaran siswa (Fikri \& Romadon, 2019).

Metode pembelajaran Team Teaching ini memberikan peluang yang luar biasa bagi setiap guru untuk melakukan pengembangan diri serta untuk meningkatkan belajar siswa (Azni \& Jailani, 2015). Selain itu metode Team Teaching ini akan meningkatkan kualitas persiapan dalam kegiatan pembelajaran dan semua perangkat pendukung belajar mengajar serta memaksimalkan semua potensi yang ada, baik potensi SDM (Sumber Daya Manusia) berupa guru - guru yang disiplin ilmu serta memaksimalkan potensi sarana prasarana yang diperlukan dalam pelaksanaaan program pembelajaran (Hasibuan, 2016). Dengan demikian kualitas hasil belajar mengajar di kelas meningkat dan rasa percaya diri dan motivasi guru untuk menyajikan materi pembelajaran serta pemanfaatan fasilitas dapat dioptimalkan begitupun siswa mereka akan mendapatkan haknya yaitu mendapatkan ilmu (Maryamah, 2016).

Ponorogo salah satu kabupaten yang ada diwilayah jawa timur, kota ini sering dijuluki atau biasa dikenal sebagai kota santri dan seni. Dalam menunjang pendidikan dan pengetahuan penduduk ponorogo tentunya di kota ini juga banyak sekali madrasah ataupun sekolah baik negeri maupun swasta (Kementrian Agama RI Direktoral Jenderal Pendidikan Islam, 2019). Beberapa sekolah swasta yang ada di Ponorogo ini, merupakan sebuah sekolah atau madrasah yang didirirkan oleh organisasi - organisasi islam seperti Muhammadiyah dan Nahdlatul Ulama.

Jika dilihat sistem pembelajaran ataupun metode yang digunakan didalam kelas, tidak banyak sekolah ataupun madrasah yang ada di Ponorogo ini menerapkan Metode Team Teaching dalam kegiatan pembelajaran didalam kelas. Mayoritas kegiatan pembelajaran yang dilaksanakan oleh seorang guru di beberapa lembaga sekolah ataupun madrasah di Ponorogo ini masih dilaksanakan secara individu, mulai dari proses perencanaan, pembelajaran, evaluasi sampai dengan penilaian siswa.

Salah satu lembaga pendidikan yang menerapkan metode Team Teaching disekolah yaitu salah satu madrasah dibawah naungan organisasi Muhammadiyah. Peneliti sangat tertarik untuk melaksanakan penelitian di MI Muhammadiyah 6 Nglegok Jenangan Ponorogo, karena Madrasah ini telah melaksanakan kegiatan pembelajaran dengan menggunkaan metode Team Teaching. Saat ini MI Muhammadiyah 6 Nglegok Ponrogoo sudah menginjak tahun ke empat dalam kegiatan pembelajaran dengan metode Team Teaching. Oleh karean itu, peneliti ingin mengetahui lebih mendalam tentang latar belakang perumusan metode Team Teaching bagaimana manajemen didalamnya sehingga metode ini bisa terlaksana dengan baik di Madrasah ini . 
MI Muhammadiyah 6 Nglegok Jenangan Ponorogo merupakan sebuah lembaga pendidikan swasta dibawah naungan organisasi muhammadiyah. MI Muhammadiyah 6 Nglegok ini memiliki 6 kelas muali dari kelas I sampai dengan kelas VI, kegiatan pembelajaran yang setiap hari dilaksanakan di Madrasah ini yakni menggunakan metode Team Teaching atau yang biasa disebut satu kelas dua orang guru. Dengan adanya metode pembelajaran Team Teaching ini sangat membantu proses pembelajatan yang dilaksanakan dan siswa siswi MI Muhammadiyah 6 Nglegok Ponrogo juga bisa mendapatkan haknya secara maksimal. Harapan peneliti kedepan, penelitian ini mampu untuk dijadikan acuan guru dan mampu untuk diterapan dilembaga atau instansi yang lain.

\section{METODE PENELITIAN}

Penelitian ini merupakan sebuah penelitian kualitatif dengan pendekatan deskriptif, yakni menjelaskan dan mendeskripsikan fenomena yang ada. serta mengumpulkan data berupa kalimat-kalimat dan gambar, melakukan pengujian data dan kemudian dijelaskan sebagaimana adanya. Jenis penelitian ini merupakan penelitian yang dilakukan dilapangan, yaitu penelitian yang bertujuan untuk melakukan studi yang mendalam terhadap suatu lembaga pendidikan sehingga menghasilkan gambaran yang lengkap dan terorganisi dengan baik mengenai suatu lembaga pendidikan. Penelitian ini dilaksanakan dengan penjelasan yang berkaitan dengan Manajemen Team Teaching di MI Muhammadiyah 6 Nglegok Jenangan Ponorogo (Ikhwan, 2021).

Sumber data yang digunakan oleh peneliti dalam penelitian ini adalah primer dan skunder. Data primer merupakan data yang diperoleh dan dikumpulkan langsung dilapangan oleh orang yang melakukan penelitian disebuah lembaga atau instansi. Dalam penelitian in data sekunder berasal dari arsip - arsip atau mungkin catatan catatan yang dimiliki oleh MI Muhammadiyah 6 Nglegok Jenangan Ponorogo.

Penelitian ini menggunakan beberapa metode pengumpulan data diantaranya; teknik wawancara, teknik observasi dan teknik dokumentasi. Analisis data yang digunakan dalam penelitian ini menggunkaan analisis kualitatif, dilakukan secara terus menerus sampai tuntas. Dengan mengacu pada model karya Miles dan Huberman, yaitu data reduction, data display, dan conclusion drawing/verification (Sugiyono, 2015). Pemeriksaan keabsahan data dalam sebuah penelitian dilakukan dengan cara - cara Meningkatkan Ketekunan, Trianggulasi Data, Analisis Kasus Negatif, Menggunakan Bahan Referensi dan Mengadakan Member Check.

\section{HASIL DAN PEMBAHASAN}

\section{Manajemen Team Teaching di MI Muhammadiyah 6 Nglegok Jenangan Ponorogo}

Berdasarkan deskripsi data MI Muhammadiyah 6 Nglegok Jenangan Ponorogo dalam proses pembelajaran yang dilakukan di Madrasah ini menggunakan metode Team Teaching. Metode ini merupakan sebuah program baru yang dirumuskan oleh MI Muhammadiyah 6 Nglegok Jenangan Ponorogo guna untuk meningkatkan mutu pendidikan yang ada di madrasah ini.

MI Muhammadiyah 6 Nglegok Jenangan Ponroogo merupakan lembaga pendidikan di bawah naungan organisasi besar dunia yakni Muhammadiyah dimana madrasah ini adalah madrasah yang menerapkan adab sebelum ilmu, iman sebelum Al Qur'an. Madrasah ini juga merupakan madrasah yang letaknya jauh dari keramaian kota, namun sekarang madrasah ini lebih banyak dilirik oleh masyarakat luas termasuk masyarakat kota.

Dewasa ini banyak sekali orang tua yang mencari sekolah yang dimana ilmu agama lebih banyak diajarkan dari pada sekolah umum biasa. Orang tua akan melihat 
bagaimana mutu pendidikan di lembaga atau madrasah tersebut meski jaraknya jauh ditempuh.

Munculnya program baru yang dirumuskan oleh pihak sekolah dan beberapa tim juga menjadi hal yang menonjol di Madrasah ini. Program baru ini adalah metode Team Teaching dimana didalam satu kelas terdapat dua orang guru dalam pengelolaannya. Belum banyak sekolah yang menerapkan metode tersebut, namun MI Muhammadiyah 6 Nglegok sudah menerapkan metode mulai dari tahun 2017 yang lalu hingga sekarang.

Manfaat metode Team Teaching juga dirasakan oleh MI Muhammadiyah 6 Nglegok Jenangan Ponorogo khususnya guru atau ustadzah yang mengajar atau menjadi tenaga pendidik di Madrasah yaitu dengan adanya metode Team Teaching di MI Muhammadiyah 6 Nglegok Jenangan Ponorogo tugasnya semakin ringan dalam proses pembelajaran maupun pengelolaan kelas. Biasanya dalam satu kelas hanya diampu oleh satu orang guru saja, namun berbeda dengan metode Team Teaching, metode ini dalam satu kelas ada tim yang berjumlah dua orang dimana di MI Muhammadiyah 6 Nglegok ini setiap guru memiliki tugas dan fungsinya masing - masing jadi tidak saling tindih.

Proses pembelajaran dari awal mulai dari penyusunan rencana pembelajaran sampai dengan evaluasi akan dilaksanakan bersama dengan tim tersebut. Adapun hasil deskripsi datanya sebagai berikut:

\section{a. Planning (perencanaan)}

Berawal dengan keresahan para guru yang ada di MI Muhammadiyah 6 Nglegok Jenangan Ponorogo bahwa proses pembelajaran yang dilakukan didalam kelas selama dirasa kurang dan banyak hak anak yang belum terpenuhi secara maksimal. Hal ini akhirnya kepala sekolah dan juga guru MI Muhammadiyah 6 Nglegok Ponorogo menyusun rencana dengan beberapa tim pengembang untuk merumuskan program baru agar kedepannya MI Muhammadiyah 6 Nglegok Jenangan Ponorogo bisa lebih baik lagi.

Penyusunan program baru tersebut dilaksanakan pada awal tahun 2017 sehingga pada pertengahan tahun program baru tersebut mulai di terapkan di MI Muhammadiyah 6 Nglegok Jenangan Ponorogo. Maksud dan tujuan diterapkannya rogram baru yakni metode team teaching ini dengan tujuan untuk melakukan perubahan dimana guru dan juga ustad ustadzah yang ada di MI Muhammadiyah 6 Nglegok Jenangan Ponorogo menyadari bahwa kemampuan untuk mengkondisikan anak dengan jumlah besar tidak mampu jika diatasi sendiri, oleh karena itu pihak madrasah dengan tim pengembang serta dengan hasil musyawarh bersama memutuskan untuk menerapkan program baru yaitu metode team teaching.

Metode team teaching merupaka salah satu metode pembelajaran, dimana metode team teaching ini satu kelas diampu oleh dua orang guru atau lebih yang memiliki tugas dan tanggungjawab masing - masing terhadap siswa siswinya. Metode team teaching ini merupakan salah satu metode yang sangat meringankan beban guru, karena dengan adanya dua orang guru atau lebih seluruh tugas yang ada di kelas bisa dilaksanakan bersama - sama.

\section{b. Organizing (pengorganisasian)}

Organizing merupakan pengelompokan tugas maupun wewenang yang ada untuk memenuhi maksud dan tujuan sebuah instansi ataupun lembaga pendidikan. Begitupun yang ada di MI Muhammadiyah 6 Nglegok Jenangan Ponorogo bahwasannya untuk mencapai maksud dan tujuan madrasah disusunlah struktur organisasi agar apa yang di inginkan dapat terealisasikan dengan baik.

Hal ini dalam sebuah lembaga pendidikan Kepala Sekolah berhak untuk menunjuk siapa saja yang dirasa mampu untuk membantu menjalankan roda organisasi. Hal ini 
Kepala Madrasah Ibtidaiyah Muhammadiyah 6 Nglegok Jenangan Ponorogo berhak menunjuk siapa saja yang dirasa mampu untuk mengkondisikan siswa dan juga menyampaikan materi didalam kelas.

Susunan organisasi yang ada di MI Muhammadiyah 6 Nglegok Jenangan Ponorogo dalam pembagian tugas guru adalah dengan membagi dua orang guru dalam satu kelas dimana dua orang guru ini saling bekerjasama dan berkolaborasi untuk mewujudkan tujuan madrasah juga agar siswa bisa terkondisikan dengan baik dan mendapatkan haknya masing - masing sebagai seorang siswa.

Team teaching merupakan salah satu program yang ada di MI Muhammadiyah 6 Nglegok Jenangan Ponorogo untuk menunjang mutu pendidikan yang ada di Madrasah tersebut. Team Teaching di MI Muhammadiyah 6 Nglegok Jenangan Ponorogo merupakan dua orang guru yang mengampu satu kelas yang biasa disebut guru adab dan guru Al-Qur'an, guru adab adalah guru yang menyampaikan materi umum sedangkan guru Al- Qur'an merupakan guru yang menyampaikan materi agama dan juga bertugas dalam kegiatan tahfidz atau hafalan Al-Qur'an. Guru adab dan guru AlQur'an ini saling bekerjasama untuk mengkondisikan siswa dikelas dan juga menyiapkan seluruh perangkat pembelajaran yang digunakan.

\section{c. Actuanting (pergerakan)}

Prinsip actuanting ini dalam sebuah lembaga pendidikan tentunya menjadi salah satu inti dari proses manajemen. Dimana pergerakan ini jika dalam lembaga pendidikan yang menjadi roda penggerak adalah guru. Guru menjadi objek dimana guru harus mampu menyajikan pembelajaran yang ada didalam kelas dengan baik.

MI Muhammadiyah 6 Nglegok Jenangan Ponorogo dalam pergerakannya sendiri yakni dengan menyiapkan berbagai perangkat pembelajaran mulai dari model, metode dan materi pembelajaran yang ada didalam kelas agar maksimal. Guru juga menjadi salah satu penentu keberhasilan siswa, karena guru lah yang menjadi tauladan serta kaca bagi siswa siswi nya.

Proses pembelajaran yang ada di MI Muhammadiyah 6 Nglegok Jenangan Ponorogo dikoordiner langsung oleh ustad dan ustadzah yang ada di Madrasah tersebut mulai dari siswa masuk kelas, langkah - langkah pembelajarannya sampai siswa siswi meninggalkan kelas. Adanya program baru yakni metode team teaching di MI Muhammadiyah 6 Nglegok Jenangan Ponorogo menjadikan tugas guru lebih ringan dan tentunya ada patner yang bisa diajak untuk komunikasi, koordinasi dan saling memotivasi.

\section{d. Controlling}

Kegiatan controlling atau pengawasan dalam sebuah lembaga pendidikan dipandu langsung oleh Kepala Sekolah. Begitupun yang ada di MI Muhammadiyah 6 Nglegok Jenangan Ponorogo dalam proses pembelajaran dengan menggunakan metode team teaching ini setiap minggunya diadakan evaluasi bersama antara kepala sekolah dan juga ustad ustadzah. Dimana hal ini menjadikan organisasi yang ada di MI Muhammadiyah 6 Nglegok Jenangan Ponorogo ini tersusun dengan rapi.

Controlling atau pengawasan merupkan salah satu hal yang sangat penting, karena dengan adanya pengawasan inilah tugas dan pekerjaan bisa diukur keberhasilannya juga kepala Madrasah bisa mengetahui setiap hambatan yang dihadapi oleh masing masing guru serta kepala Madrasah memberikan bimbingan dan jug dorongan untuk selalu memperbaiki tidak semata - mata mencari kesalahan.

\section{Faktor Pendukung dan Faktor Penghambat Manajemen Team Teaching di MI Muhammaidyah 6 Nglegok Ponorogo}


Terlaksananya manajemen Team Teaching di MI Muhammadiyah 6 Nglegok Jenangan Ponorogo dipengaruhi beberapa faktor pendukung, diantaranya:

\section{a. Guru atau Ustad dan Ustadzah}

Guru atau Ustad dan Ustadzah berperan penting dala pelaksanaan manajemen Team Teaching yang ada di MI Muhammadiyah 6 Nglegok. Guru sebegai perencana sekaligus pelaksana dalam pembelajaran di kelas dengan metode Team Teaching. Dalam sebuah lembaga pendidikan tentunya siswa siswi menjadi tanggungjawab semua pihak madrasah, namun dalam hal ini yang menjadi penanggung jawab penuh adalah guru atau ustad dan ustadzah.

Menurut Thomas E. Curtis dan Wilma W. Bidwelll bahwa proses pembelajaran di sekolah atau dikelas peranan guru sangat spesifik sifatnya dalam pengertian yang sempit dalam hubungan belajar mengajar. Peranan guru sebagai pengorganisasian dalam lingkungan belajar dan juga guru sebagai fasilitator belajar. Sehingga dalam hal ini guru atau ustad dan ustadzah sebagai pengganti orang tua selama belajar di sekolah.

Guru atau ustad dan Ustadzah yang ada di MI Muhammadiyah 6 Nglegok Jenangan Ponorogo, merupakan salah satu faktor pendukung terlaksananya manajemen Team Teaching yang ada di Madrasah ini. Dimana dalam pelaksanaan manajemen Team Teaching yang sangat berpengaruh adalah guru, dimana guru yang memanajemen bagaiamana agara kelas tersebut bisa dikondisikan dengan baik.

Oleh karena itu di MI Muhammadiyah 6 Nglegok Ponroogo, guru dibagi menjadi dua guru adab dan guru Al-Qur'an. Dalam hal ini kedua guru tersebut harus saling berkoordinasi antar satu dengan yang lain untuk memanajemen kelas. Guru juga harus paham terhadap tupoksinya masing - masing dalam metode Team Teaching yang dilaksanakan di Madrasah. Guru yang berkualitas adalah guru yang akan selalu belajar untuk menyuguhkan bagaimana yang terbaik untuk siswa siswi nya.

\section{b. Siswa}

Dalam lembaga pendidikan tentunya siswa juga menjadi faktor pendukung dalam sebuah keberhasilan. Metode Team Teaching yang ada di MI Muhammadiyah 6 Nglegok Jenangan Ponorogo tentunya juga harus mendapatkan respon yang baik oleh siswa siswi madrasah. Hal ini siswa menjadi titik fokus dalam sebuah pembelajaran, karean dengan adanya metode team teaching ini madrasah berharap siswa siswi mendapatkan haknya sebagai siswa, yaitu menerima materi dengan baik, jika ada salah satu siswa yang bermasalah maka akan diselesaikan dengan baik tanpa mengganggu siswa yang lain, karena dalam hal ini guru sudah menyusun tupoksi masing - masing ketika didalam kelas.

\section{c. Sarana dan Prasarana}

Sarana dan prasarana dalam sebuah lembaga pendidikan tentunya sangat penting. Karena sarana prasarana juga menjadi salah satu penunjang keberhasilan visi, misi dan tujuan madrasah. Seperti di MI Muhammadiyah 6 Nglegok Jenangan Ponorogo, sarana dan prasarana merupakan salah satu faktor yang menjadi pendukung dalam pelaksanaan manajemen Team Teaching. Madarsah ini sudah memiliki fasilitas atau sarana prasarana yang sudah lengkap, mulai dari ruang kelas, ruang guru, ruang kepala madrasah, kamar mandi, masjid, lapangan dan lain sebagainya. Hal ini sudah menjadi nilai plus MI Muhammadiyah 6 Nglegok karena dalam kegiatan belajar mengajar sudah ada di gedung pribadi artinya tidak menyewa.

Sedangkan kata penghambat menurut Kamus Besar Bahasa Indonesia diartikan sebagai hal, keadaan atau penyebab lain yang menghambat (merintangi, menahan, menghalangi). Sedangkan pengertian dari hambatan adalah suatu yang dapat 
mengahalangi kemajuan dan keberhasilan suatu hal. Pada penelitian ini faktor penghambat manajemen Team Teaching didefinisikan sebgaai hal atau keadaan yang dapat menghambat dan mengahlangi pelaksanaan metode Team Teaching.

Sesuai hasil penelitian dan observasi di MI Muhammadiyah 6 Nglegok Jenangan Ponorogo ditemukan beberapa penghambat yang dialami di MI Muhammadiyah 6 Nglegok Jenangan Ponorogo dalam manajemen Team Teaching yaitu:

Pertama, kurangnya komunikasi antar guru dan orangtua atau walimurid. Dalam lembaga pendidikan tentu peran orangtua sangat penting dalam proses belajar mengajar siswa. Namun, dalam hal ini tidak sedikit orangtua yang selalu mensuport dan paham akan pelaksanaan pembelajaran di madrasah. Masih banyak walisantri yang kadang belum paham dan terkadang langsung datang ke sekolah untuk meminta kejelasan dari guru atau ustadz dan ustadzah. Hal ini tentunya kurang baik, maka komunikasi antar guru dan juga walisantri harus dijaga dengan baik sehingga tidak ada kesalahpahaman antar guru dan siswa. Kedua, adanya masyarakat yang masih kurang percaya dan berfikir negatif terhadap madrasah tentang program dan layanan yang diberikan kepada siswa - siswinya.

\section{KESIMPULAN DAN SARAN}

Manajemen Team Taeching di MI Muhammmadiyah 6 Nglegok Ponorogo merupakan sebuah program baru, metode pembelajaran Team Teaching yang dilaksanakan dengan tujuan untuk menunjang keberhasilan mutu pendidikan madrasah. Manajemen Team Teaching ini dalam satu kelas terdapat dua guru didalamnya yaitu guru adab dan guru qur'an, dimana masing - masing guru memiliki tugas dalam pengelolaan kelas. Pelaksanaan Team Teaching sangat membantu terselenggaranya pembelajaran dikelas dengan baik karena diampu oleh dua orang guru. Hal ini bertujuan agar siswa siswi dapat memperoleh hak nya sebagai siswa yakni mendapatkan ilmu.

Faktor yang menjadi pendukung terselenggaranya metode Team Teaching di MI Muhammadiyah 6 Nglegok yaitu adanya dukungan dari Tim Pengembang, Kepala Madrasah, guru atau ustad dan ustadzah, siswa serta sarana prasarana yang ada di MI Muhammadiyah 6 Nglegok. Sedangkan faktor penghambat terselenggaranya metode Team Teaching di MI Muhammadiyah 6 Nglegok Jenangan Ponorogo yaitu, kurangnya ilmu dan pengetahuan yang dimiliki oleh guru sehingga terkadang masig ada materi yang belum tersampaikan dengan baik selanjutnya kurannya komunikasi antar guru dan juga pihak orangtua sehingga sering terjadi kesalah pahaman.

\section{REFERENSI}

Afandi, M. (2013). Model Dan Metode Pembelajaran Di Sekolah. Semarang: Sultan Agung Press.

Anwar, S. (2021). Pendidikan Karakter: Kajian Perspektif Tafsir fi Zilalil Qur'an. Tulungagung: STAI Muhammadiyah Tulungagung.

Anwar, S. (2022). Evaluasi Pendidikan Menuju Insan Kamil Perspektif Filsafat Islam. JURNAL PENDIDIKAN NUSANTARA, 1(1), 62-76.

Arief, A. (2002). Pengantar Ilmu dan Metodologi Pendidikan Islam. Jakarta: Ciputar Pers.

Azni, T. N., \& Jailani, J. (2015). Pengembangan Perangkat Pembelajaran Trigonometri Berbasis Strategi Pembelajaran Inkuiri Melalui Model Pembelajaran Kooperatif Tipe Stad. Jurnal Riset Pendidikan Matematika, 2(2), 284. https://doi.org/10.21831/jrpm.v2i2.7347

Darmadi, H. (2015). Tugas, peran, kompetensi, dan tanggung jawab menjadi guru 
profesional. Jurnal Edukasi.

Fikri, A. Z., \& Romadon, M. H. (2019). Analisis Penerapan Metode Team Teaching Di Kelas 3 SD STKIP Muhammadiyah Bangka Belitung. Prosiding Semnasfip.

Gazali, M. (2013). Optimalisasi Peran Lembaga Pendidikan Untuk Mencerdaskan Bangsa. Jurnal Al-Ta'dib, 6(1), 126-136.

Hamalik, O. (2001). Proses Belajar Mengajar. Bandung: Bumi Aksara.

Hasibuan, M. S. P. (2016). Manajemen Sumber Daya Manusia. Jakarta: Bumi Aksara.

Ikhwan, A. (2021). Metode Penelitian Dasar (Mengenal Model Penelitian dan Sistematikanya). Tulungagung: STAI Muhammadiyah Tulungagung.

Kementrian Agama RI Direktoral Jenderal Pendidikan Islam. (2019). Data Lembaga Kabupaten Ponorogo (Rekapitulasi Data Pokok Pendidikan Islam Madrasah 2018/2019).

Maryamah, I. Y. (2016). Penerapan Metode Mengajar Beregu (Team Teaching) dalam Meningkatkan Hasil Belajar Siswa Kelas IV pada Mata Pelajaran SKI di MI Muhammadiyah Ulak Lebar Kecamatan Ulo Ogan Kabupaten OKU. JIP: Jurnal Ilmiah PGMI, 2(1).

Mubarak, A. Z. (2018). Pendidikan di era revolusi industri 4.0 dan problematika penddiikan tinggi. Yogyakarta: Gading Pustaka.

Muhaimin. (2004). Paradigm Pendidikan Islam. Bandung: PT Remaja Rosdakarya.

Peraturan Pemerintah RI. Undang - Undang Republik Indonesia tentang Sistem Pendidikan Nasional. , (2003).

Ramadhani, Y. R., Masrul, M., Ramadhani, R., Rahim, R., Tamrin, A. F., Daulay, J. S., ... Simarmata, J. (2020). Metode dan Teknik Pembelajaran Inovatif. Medan: Yayasan Kita Menulis.

Ridwan, Y., \& Ikhwan, A. (2021). Education of Religious Characters in Indonesia. 2nd Annual Conference on Blended Learning, Educational Technology and Innovation (ACBLETI 2020), 435-440. Atlantis Press.

Siregar, M., Zahra, D. N., \& Bujuri, D. A. (2020). Integrasi Materi Pendidikan Agama Islam Dalam Ilmu-Ilmu Rasional Di Sekolah Menengah Atas Islam Terpadu. AlTadzkiyyah: Jurnal Pendidikan Islam, 10(2), 183-201. https://doi.org/10.24042/atjpi.v10i2.4847

Sugiyono. (2015). Metode Penelitian dan Pengembangan. Bandung: Alfabeta.

Suttrisno, S., Riyanto, Y., \& Subroto, W. T. (2020). Pengaruh Model Value Clarification Technique (Vct) Berbasis Kearifan Lokal Terhadap Motivasi Belajar Dan Hasil Belajar Siswa. NATURALISTIC : Jurnal Kajian Penelitian Pendidikan Dan Pembelajaran, 5(1), 718-729. https://doi.org/10.35568/naturalistic.v5i1.836

Usman, M. U., \& Setiawati, L. (1993). Upaya Optimalisasi Kegiatan Belajar Mengajar (Bahan Kajian PKG, MGBS, MGMP). Bandung: Remaja Rosdakarya.

Yani, M. T., Setyowat, R. N., Islamiyah, D. N., \& Pranggono, G. (2014). Konstruksi Kurikulum dan Pembelajaran Terpadu antara Pendidikan Agama Islam (PAI) dan Pendidikan Kewarganegaraan (PKn) di Sekolah Dasar. ISLAMICA: Jurnal Studi Keislaman, 6(1), 168. https://doi.org/10.15642/islamica.2011.6.1.168-179 